\title{
Partisan Competition, Growth and the Franchise*
}

\author{
Humberto Llavador ${ }^{\dagger} \quad$ Robert J. Oxoby ${ }^{\ddagger}$
}

September 16, 2004

\begin{abstract}
We present an argument for changes in the franchise in which an elite split along economic interests use the suffrage to influence implemented policies. Through the influence of these policies on the character of industrialization, we analyze the effects of franchise changes on economic growth. We identify in the social structure of society an explanation for the connection between enfranchisement and growth: When (1) there exist an economic conflict among the elite, (2) landed classes are not politically strong, and (3) there exists a critical mass of industrial workers, we observe both growth and democratization. The lack of conditions (1) or (2) resolves in stagnant autocracies while the absence of condition (3) drives growth-deterring democratic expansions. We provide historical support for our argument by analyzing the experience of 11 countries.
\end{abstract}

KEYWORDS: Franchise, growth, political competition, elites, industrialization.

JEL Classification: D72, D74, N10, 041, P16

*We thank Azim Essaji, Bernard Grofman, Alesandro Lizzeri, Peter Swenson and seminar participants at MIT, UPF, and Yale for helpful comments and suggestions.

${ }^{\dagger}$ Corresponding author: Dept. of Economics, University Pompeu Fabra, R. Trias Fargas, 25-27, 08005 Barcelona Spain; tel.: (+34) 93542 2381, humberto.llavador@upf .edu.

${ }^{\ddagger}$ Dept. of Economics, University of Calgary, 2500 University Drive NW, Calgary AB Canada T2N 1N4; tel.: 4032202586 , oxoby@ucalgary.ca 
[W] learn [from nineteenth century developments] that the state's influence on the economy depended critically on who controlled the state. (Adelman, 1999)

\section{Introduction}

The nineteenth century was a time of rapid economic growth and development. Over this period, the seeds sown by the industrial revolution were realized by expansions in technology and markets. As important as changes in the structure of industry and markets, the nineteenth century was also a period of significant fluctuations in the structure and allocation of political rights. Many countries saw large-scale changes in the distribution of political voice, changes leading not only to increases in the electorate, but also to massive decreases.

The concurrence of changes in the "engines of economic growth" and this "first wave" of changes in the franchise is not coincidence. ${ }^{1}$ When one considers a pre-industrial or early industrialized society comprised of different social groups, one can imagine preferences over the character of economic growth to differ across (and potentially within) each group. As such, the enfranchisement or disenfranchisement of these groups is a means for political parties to pursue economic policies benefitting their constituencies.

In this paper we present a theory of franchise changes in which an elite split along economic interests use the suffrage to influence implemented policies and hence, growth. Specifically, we take economic policies to asymmetrically affect different economic sectors, raising productivity in only the skilled sector which drives economic growth (in our model, industry). These policies can be construed as any government intervention promoting industrialization, like the reduction of tariffs, the creation/promotion of national markets, investment in infrastructure, education or health care. Given the asymmetric sectoral benefits of these policies, political parties representing the different economic interests of elites may shape political institutions (and in particular the electorate) in order to control

\footnotetext{
${ }^{1}$ The argument that the industrial revolution triggered the process of democratization can be traced back to the work of Toynbee (1884).
} 
policies, thereby influencing the realization of potential growth opportunities. Thus our theory develops our understanding of the interrelation between the franchise and economic growth, highlighting the pivotal roles played by governments in promoting the industrial revolution (Adelman, 1999).

A key element for our argument is that political parties represent the different interests of an elite divided on an economic cleavage. This cleavage has been traditionally identified with the rural-urban cleavage, but its historical realizations took many different forms. For example, in Switzerland Liberals favored the promotion of commerce and a unified market, while Conservatives defended a decentralized confederation that maintained their cantonal 'monopolies'. In Canada the conflict concentrated on the terms of trade with the U.S. In Sweden, it was not until the end of the century that the split of the dominant Agrarian Party on free-trade/protectionism made suffrage the most important issue.

Given the conflicting interests among the elite, parties look in the disenfranchised groups for the necessary political support to implement their preferred policies. In our model, it is precisely this type of alignment or misalignment of policy preferences between groups among the elite and workers which provides an explanation for extensions and restrictions of the franchise. For example,

when he [Chancellor Otto Furst von Bismark] promoted universal suffrage in the North German Confederation (and later the German Empire)... [he] implicitly expected that peasants, who were largely loyal to the king, would also be obedient to their manor lords and employers when voting (Colomer, 2001).

Our theory yields several insights into the tandem relation between economic growth and democratization. Following the opening quotation, "economies controlled by feudal landed interests could only achieve narrow-based growth without development and presented no extensions of the franchise (Adelman, 1999). On the other hand, in early stages of industrial development liberals typically promoted extending the franchise to workers against the opposition of conservatives. This permitted governments to pursue active industrial and market policies, thereby sustaining higher levels of economic growth. However, 
these extensions were limited: Once enough workers had been enfranchised, the policies favored by liberals were secured and further expansions were opposed. For example, Danish Liberal Prime Minister J.C. Christensen froze any electoral change when suspected his party would not benefit (Elklit, 2002). Moreover, if conservatives expected an alignment of interests between landlords and peasants, conservatives opted for universal suffrage. This effectively quashed economic policies favoring industrialization, stalling the process of economic growth. For example, in 1874 Chilean conservatives pushed for extending the franchise into poorer agriculturalists considered supportive of conservative policies (Valenzuela, 1996). This ushered in a period of policies favoring agricultural and mineral exports and the virtual neglect of urban and industrial infrastructure.

Our theory also casts democratic expansion as a "trickle down" process: Policy-driven industrial development raises industrial productivity and industrial wages. Given the presence of wealth and income requirements during the nineteenth century, these policies raised the incomes of workers and effectively enfranchised them over time. ${ }^{2}$ Therefore, provided a democratic institution exists, growth of technology and wages naturally leads to a diffusion of voting rights. Following Persson and Tabellini (1994), while democracy may be harmful for economic growth, economic growth is good for democracy.

The remainder of the paper is organized as follows. Section 2 reviews the related literature, delineating the ways our approach improves the understanding of franchise reforms above existing theories. The economic and political models are described in section 3 . The next two sections contain our main results: Section 4 presents our argument for changes in the franchise and section 5 analyzes the connections between patterns of enfranchisement and economic growth. Section 6 analyzes the historical experiences of eleven countries and finds support for our theory. While our focus is on the changes in the franchise implemented during the nineteenth century, the argument can be applied to more recent changes in voting laws. ${ }^{3}$ Section 7 concludes.

\footnotetext{
${ }^{2}$ For example, rising wages in Sweden resulted in an increase in the electorate over the period 1872-1908: without legislative changes, the percentage of enfranchised males increased from $22 \%$ to $33 \%$ in rural areas and from $21 \%$ to $45 \%$ in urban areas (Heckscher, 1963).

${ }^{3}$ For example, the "motor voter" legislation in the U.S. reduced many of the costs of voting, particularly
} 


\section{Related Literature}

Our research builds on the growing literature exploring the process of democratization. Much of this literature builds on the de Toquevillian paradox implicit in the work of Persson and Tabellini (1994): If greater democracy (extension of the franchise) implies a poorer median voter, and hence higher levels of redistribution, why would elites choose to extend voting rights?

In response to this paradox, much attention has been paid to the processes of democratization arising from threats "from below:" elites may extend the franchise in order to quell revolutionary threats from the disenfranchised. In the work of Acemoglu and Robinson $(2000,2001)$, elites opt for universal suffrage in order to make a credible commitment to redistribution and eliminate the threat of revolution. ${ }^{4}$ In a similar vein, Conley and Temimi (2001) argue that investments in "threat technologies" increase the likelihood that a disenfranchised group is allocated voting rights.

Unlike our analysis, Acemoglu and Robinson (2000) assume a homogenous elite and a government restricted to pure redistribution. Thus, the only motivations for electoral reform come from disenfranchised groups. Those groups must therefore be sufficiently organized to pose a credible threat (recall Conley and Temimi, 2001). This is why many of their historical references fall in the early twentieth century after the organization of the working class, while our argument presents a better fit with the nineteenth century experiences of political reform. See section 6 for details. ${ }^{5}$

In a spirit similar to ours, Lizzeri and Persico (2004) argue that elites may wish to extend the franchise in order to steer politicians away from causes serving narrow constituencies

those facing poorer Americans. It is therefore not surprising that this legislation was supported by Democrats (who expected to gain supporters) and derided by Republicans (who expected their share of supporters among the electorate to fall).

${ }^{4}$ Lee (2003) focuses on the relation between democracy and redistributive bias by elites: while democratization reduces predation by elites (the "Olson effect") it implies a poorer median voter and greater redistribution (the "de Tocqueville effect").

${ }^{5}$ Observe that our argument falls far from the political competition theories criticized by Acemoglu and Robinson (2000). These theories envision power-motivated politician who extend the franchise expecting votes in return; our argument is deeply rooted in the alignment of economic interests between a split elite and disenfranchised groups. Therefore Acemoglu and Robinson's evidence contradicting these theories (pages 1187-1189) is explained by our arguments, as we show in section six for UK, Germany, Sweden and France. 
and towards policies with more diffuse benefits. Enfranchising of individuals beyond the elite forces politicians to garner support through the provision of public goods benefiting the whole electorate. The model's implications are used to explain the increases in public spending witnessed during Britain's "Age of Reform." 6

While we and Lizzeri and Persico (2004) emphasize heterogeneous preferences among the elite, our argument underscores the roles of political parties and the interests of the social groups they represent. As a result, our model explains why different political groups favored different levels of enfranchisement (e.g. Orleanists versus Legitimists in France, the Liberal Movement versus Bismark in Germany). ${ }^{7}$ Further we tie these franchise levels to the implementation of economic policies, thereby illuminating the conditions under which the extent of the electorate can foster or forestall economic growth.

Finally we stress two ways in which our argument improves the understanding of franchise reform above existing theories. First, our theory provides and explanation for two historically repeated observations: (i) the rich history of franchise restrictions and (ii) the tendency for conservative governments to support larger extensions than liberal governments. For example, in France (1850) and Canada (1885) conservatives significantly restricted the franchise to an elite dominated by conservative voters. On the other hand, in Chile (1874) and Germany (1871) conservative interests supported large extension of the franchise in an effort to swamp liberal interests. Secondly, our theory identifies the nexus between enfranchisement, economic policy and growth during the nineteenth century, a time when it is widely acknowledged that governments played a critical role (Adelman, 1999; Morris and Adelman, 1988).

In line with these conclusions are Engerman and Sokoloff (2001), Sokoloff and Engerman

\footnotetext{
${ }^{6}$ Other models of franchise extension include Bertocchi (2003, emphasizing the relation between primogeniture and the indivisibility of land in the diffusion of voting rights), Fleck and Hanssen (2002, emphasizing the inconsistency of aristocrats desiring human capital investment among the lower classes and wishing to expropriate these investment) and Llavador and Oxoby (2002, emphasizing the second-order effects of changes in the electorate on equilibrium policy proposals).

${ }^{7}$ With non-ideological political competition, swing voters should receive large transfers prior to the extension of the franchise. This conclusion is difficult to reconcile with the view that the landed aristocracy benefited from the pre-extension political system (Parente and Zhao, 2002; Galor et al., 2002). By incorporating economic interests in the political arena, we find a historically consistent result in which the landed aristocracy controlled and benefited from the political system prior to the extensions of the suffrage.
} 
(2000), and Sokoloff (2002). Sokoloff and Engerman (2000) argue that, although South America had greater factor endowments than North America, the relative inequality of political rights limited its potential for growth in the New World. South American countries were dominated by landed interests who, as in our model, had little incentives to invest in public goods which increased workers skills (e.g. education). Thus, in line with Acemoglu and Robinson (2000), Benabou (2000) and Saint-Paul and Verdier (1993),

An extension of political power beyond an elite to a broad spectrum of the population might, for example, be expected to lead to greater investment in infrastructure and other public goods and services conducive to growth... a wider participation of the population in a commercial activity and economic matters generally, and perhaps more competition throughout the economy. (Engerman and Sokoloff, 2001, p.2)

However, elites were reluctant to extend political power, using, for example, poll taxes to exclude immigrants and non-Europeans from exercising voting rights. Similarly, after independence, Spanish colonies shifted from wealth to literacy requirements in order enfranchise criollo supporters and disenfranchise non-favorable groups (i.e. Native Americans). Generally speaking, countries with greater equality and homogeneity among the population observed faster and deeper extensions of the franchise, an argument also present in Colomer (2001). This equality and homogeneity result in fewer differences in policy preferences, facilitating extension of the franchise.

As with the previous papers, in which democratization and deeper extensions of the franchise helped speed economic growth, Justman and Gradstein (1999) argue that the extensions of the franchise exhibited in nineteenth century Britain were triggered by the Industrial Revolution (cf. Toynbee, 1884). These changes in the franchise were both the outcome of and a channel through which income inequality was reduced. As evidence, Justman and Gradstein (1999) cite the increases in public expenditures dedicated to productive investments which, consistent with our model's predictions, occurred after extension of the 
franchise. $^{8}$

\section{The Model}

We assume a society populated by a continuum of agents belonging to one of three classes: landlords $(l)$, capitalists $(c)$ and workers $(\mathrm{w})$, with the latter endogenously split between the skilled $(s)$ and unskilled $(u)$ sectors of the economy. The set of classes is given by $J=\{l, c, \mathrm{w}\}$, each with mass $\eta_{j} \in(0,1)$ and $\eta_{l}+\eta_{c}+\eta_{\mathrm{w}}=1$ and the mass of workers divided between $\eta_{s}+\eta_{u}=\eta_{\mathrm{w}}$. Within each class, agents are differentiated by their initial endowments $\theta$ (wealth or innate skill). We use classes to represent differences in access to production technologies.

Landowners and Capitalists: Landowners and capitalists are endowed with non-wage incomes $\theta_{j} \in\left[\underline{\theta}_{j}, \bar{\theta}_{j}\right]$, with continuous distribution $F_{j}, j \in\{l, c\}$. We assume that landowners and capitalists constitute the elite in that they control the agricultural and the industrial sectors of the economy.

We interpret the agricultural sector as the unskilled sector, represented by the production technology $g_{l}\left(L_{l}\right)=M L_{l}^{1-\alpha}$, where $\alpha \in(0,1), L_{l}$ is the amount of labor employed in agriculture, and the technological parameter $M$ is determined exogenously. In the industrial (skilled) sector of the economy capitalists are able to exploit the skills of workers in accord with the production technology $g_{c}\left(L_{c}\right)=N L_{c}^{1-\beta}$, where $\beta \in(0,1), L_{c}$ is the efficiency units of labor employed in industry, and $N$ is a technological parameter.

Given a pair of competitively determined wages, an agricultural wage $w_{l}$ and an industrial wage per efficiency unit of labor $w_{c}$, landowners and capitalists maximize profits by choice of $L_{l}$ and $L_{c}$. Letting $\pi_{l}$ and $\pi_{c}$ be the associated profit functions, the income of a member of the elite is given by $\theta_{j}+\pi_{j}\left(w_{j}\right)$ with $j=l$ for landlords and $j=c$ for capitalists.

\footnotetext{
${ }^{8}$ Bourguignon and Verdier (2000) claim that political participation increases as the result of the decision by elites to subsidize the education of the poor under the auspices of spurring economic growth. This timing of events (investment in public goods engendering democratic reform) differs from our timing (democratic reforms engendering investment in public goods). More akin to our timing of events is that discussed in Fleck and Hanssen (2002): Without voting rights, individuals do not invest in human capital from fear of expropriation by elites.
} 
Workers: As opposed to landowners and capitalists, workers have no access to technology nor possess non-wage income. Rather, each worker is endowed with a skill level $\theta_{\mathrm{w}} \in\left[\underline{\theta}_{\mathrm{w}}, \bar{\theta}_{\mathrm{w}}\right]$ with continuous distribution $F_{\mathrm{w}}$. Workers inelastically supply a single unit of labor in either the skilled or unskilled sector. If an agent chooses to work in agriculture, she receives the wage $w_{l}$. However, in the industrial sector, an agent exerts $\theta_{\mathrm{w}}$ efficiency units of labor and receives income $\theta_{\mathrm{w}} w_{c}$.

We assume that workers can costlessly migrate between sectors. Hence, the supply of labor in each sector will depend on relative wages. In particular, workers with skills $\theta_{\mathrm{w}} \geq \frac{w_{l}}{w_{c}}$ choose to work in the industrial sector, while those with skills $\theta_{\mathrm{w}}<\frac{w_{l}}{w_{c}}$ supply labor to the agricultural sector. Thus, $\eta_{s}=\left(1-F_{\mathrm{w}}\left(\frac{w_{l}}{w_{c}}\right)\right) \eta_{\mathrm{w}}$ and $\eta_{u}=F_{\mathrm{w}}\left(\frac{w_{l}}{w_{c}}\right) \eta_{\mathrm{w}}$.

The Labor Market: Workers are hired by landowners and capitalists in a competitive labor market and wages $w_{l}^{*}$ and $w_{c}^{*}$ are uniquely determined by market clearing conditions. ${ }^{9}$

Fact 1 There exists a unique pair of wages $w_{l}^{*}$ and $w_{c}^{*}$ that clear the agricultural and industrial labor markets. Furthermore, there exists an indifferent worker of ability $\theta^{*}=\frac{w_{l}^{*}}{w_{c}^{*}}$ such that, in equilibrium, $\eta_{u}=F_{\mathrm{w}}\left(\theta^{*}\right) \eta_{\mathrm{w}}>0$ and $\eta_{s}=\eta_{\mathrm{w}}-\eta_{u}>0$.

Proof: Given the nature of the production functions $g_{l}$ and $g_{c}$, it is clear that if $\left(w_{l}^{*}, w_{c}^{*}\right)$ is an equilibrium, then $\eta_{u}>0, \eta_{s}>0$, and there exists an indifferent worker of ability $\theta^{*}=\frac{w_{l}^{*}}{w_{c}^{*}}$. Hence any pair of equilibrium wages solves the market clearing conditions

$$
\begin{aligned}
& \left(\frac{(1-\beta) N}{w_{c}}\right)^{1 / \beta} \eta_{c}=\eta_{\mathrm{w}} \int_{\theta^{*}}^{\bar{\theta}_{\mathrm{w}}} \theta_{\mathrm{w}} d F_{\mathrm{w}} \quad \text { and } \\
& \left(\frac{(1-\alpha) M}{w_{l}}\right)^{1 / \alpha} \eta_{l}=\eta_{\mathrm{w}} F_{\mathrm{w}}\left(\theta^{*}\right),
\end{aligned}
$$

where left hand sides represent labor demand and right hand sides represent labor supply.

\footnotetext{
${ }^{9}$ It is widely accepted that, even during the 19th century, "industry and agriculture competed for labor, even though labor was by no means scarce." (Magnac and Postel-Vinay, 1997)
} 
Letting $\mu\left(\theta^{*}\right)=\int_{\theta^{*}}^{\bar{\theta}_{\mathrm{w}}} \theta_{\mathrm{w}} d F_{\mathrm{w}}$ and dividing equation (1) by equation (2) yields

$$
\frac{\eta_{c}^{\beta} \eta_{\mathrm{w}}^{\alpha}}{\eta_{l}^{\alpha} \eta_{\mathrm{w}}^{\beta}} \frac{(1-\beta) N}{(1-\alpha) M} \theta^{*}=\frac{\mu\left(\theta^{*}\right)^{\beta}}{F_{\mathrm{w}}\left(\theta^{*}\right)^{\alpha}}
$$

The left hand side of equation (3) is strictly positive, continuous and monotone increasing in $\theta^{*}$. The right hand side is continuous and monotone decreasing in $\theta^{*}$, approaching infinity as $\theta^{*} \rightarrow \underline{\theta}_{\mathrm{w}}$ and equal to zero when $\theta^{*}=\bar{\theta}_{\mathrm{w}}$. Therefore, there exists a unique $\theta^{*} \in\left[\underline{\theta}_{\mathrm{w}}, \bar{\theta}_{\mathrm{w}}\right]$ solving (3). It follows that $w_{l}^{*}$ and $w_{c}^{*}$ are uniquely defined as

$$
\begin{aligned}
& w_{c}^{*}=\frac{(1-\beta) N}{\mu\left(\theta^{*}\right)^{\beta}}\left(\frac{\eta_{c}}{\eta_{\mathrm{w}}}\right)^{\beta} \quad \text { and } \\
& w_{l}^{*}=\frac{(1-\alpha) M}{F_{\mathrm{w}}\left(\theta^{*}\right)^{\alpha}}\left(\frac{\eta_{l}}{\eta_{\mathrm{w}}}\right)^{\alpha} .
\end{aligned}
$$

\subsection{Economic Policies}

We assume that technological development occurs through economic policies asymmetrically affecting agents. Specifically, these policies increase productivity in the industrial sector without benefit to the agricultural sector. These policies encompass the development of market and legal institutions, infrastructure, education, health care, and basic research and development. In a broad sense, this set of policies should be understood as any government intervention promoting industrialization. ${ }^{10}$

Formally, we characterize these policies by the cost of their implementation, whether this cost arises through an increase in public expenditure (e.g. public investment in infrastructure) or a reduction in government revenue (e.g. through the reduction of tariffs). The productivity effect of these policies is captured through the technological parameter $N(\tau)$ where $\tau \in[0,1]$ is the tax rate (levied on income) reflecting the cost of these policies. We assume $N(0)=N_{0}>0$ to be the current technology, $N^{\prime} \equiv \partial N / \partial \tau>0$ and

\footnotetext{
${ }^{10}$ See Adelman (1999) and Morris and Adelman (1988) for the crucial importance of governments in advancing industrialization and the many ways industrialization was promoted.
} 
$N^{\prime \prime} \equiv \partial^{2} N / \partial \tau^{2}<0$ with $\lim _{\tau \rightarrow 0} N^{\prime}(\tau)=\infty$. Further, we assume economic policies to be the only source of endogenous technological change and no depreciation.

Given the competitive labor market, growth enhancing policies $(i)$ raise the marginal product of labor and $(i i)$ spur worker migration into the industrial sector. While $(i)$ increases and (ii) decreases industrial wages, the net effect of technological improvement is an increase in industrial and agricultural wages and in capitalists' profits.

Fact 2 Technological improvements (increases in N) yield (i) a migration of workers from agriculture into industry, (ii) an increase in industrial and agricultural wages, and (iii) an increase in capitalists' profits.

Proof:

(i) We can rewrite equation (3) as

$$
K_{0} N \theta^{*}-K\left(\theta^{*}\right)=0,
$$

where $K_{0}=\left(\frac{\eta_{c}^{\beta} \eta_{\mathrm{w}}^{\alpha}}{\eta_{l}^{\alpha} \eta_{\mathrm{w}}^{\beta}}\right) \frac{1-\beta}{(1-\alpha) M}>0$ and $K\left(\theta^{*}\right)=\frac{\mu\left(\theta^{*}\right)^{\beta}}{F_{\mathrm{w}}\left(\theta^{*}\right)^{\alpha}}$, with $K^{\prime}<0$. Differentiating yields

$$
\frac{\partial \theta^{*}}{\partial N}=\frac{K_{0} \theta^{*}}{K^{\prime}\left(\theta^{*}\right)-K_{0} N}<0
$$

Therefore $\theta^{*}$ is a decreasing function of $N$.

(ii) That $w_{l}^{*}$ is monotone increasing in $N$ follows from the previous point and equation (5). Finally, since $\theta^{*}$ is decreasing in $N$ and $w_{l}^{*}$ is increasing in $N, w_{c}^{*}$ must be increasing in $N$ as $\theta^{*} w_{c}^{*}=w_{l}^{*}$.

(iii) Recall that $\pi_{c}\left(w_{c}\right)=N L_{c}\left(w_{c}\right)^{1-\beta}-w_{c} L_{c}\left(w_{c}\right)$. The equilibrium industrial wage $w_{c}^{*}$ is a function of $N$ (see equation 4 ). Hence

$$
\frac{\partial \pi_{c}}{\partial N}=L_{c}\left(w_{c}^{*}\right)^{1-\beta}-\frac{\partial w_{c}^{*}}{\partial N} L_{c}\left(w_{c}^{*}\right)
$$


where we have made use of the first-order condition of profit maximization. Using the equilibrium level of efficiency units of labor $L_{c}\left(w_{c}^{*}\right)=\left(\frac{(1-\beta) N}{w_{c}^{*}}\right)^{1 / \beta} \eta_{c}$ (see equation 1 ),

$$
\frac{\partial \pi_{c}}{\partial N}>0 \Leftrightarrow \frac{\partial w_{c}^{*}}{\partial N} \frac{N}{w_{c}^{*}}<\frac{1}{1-\beta}
$$

Differentiating equation (4) to obtain $\partial w_{c}^{*} / \partial N$ and simplifying yields

$$
\frac{\partial w_{c}^{*}}{\partial N} \frac{N}{w_{c}^{*}}=1-N \beta \frac{\mu^{\prime}\left(\theta^{*}\right)}{\mu\left(\theta^{*}\right)} \frac{\partial \theta^{*}}{\partial N}
$$

From the previous points, $\frac{\partial w_{c}^{*}}{\partial N}>0$ and $\frac{\partial \theta^{*}}{\partial N}<0$ (equation 7 ), while, by definition, $\mu^{\prime}<0$. It follows that $0<\frac{\partial w_{c}^{*}}{\partial N} \frac{N}{w_{c}^{*}}<1<\frac{1}{1-\beta}$, and hence capitalists' profits are increasing in $N$.

First, landowners will oppose any positive policy as it reduces their income without any offsetting benefit. On the other hand, capitalists benefit from the policy (Fact 2). We can write disposable income of a capitalist endowed with $\theta_{c}$ as $y_{c}(\tau)=(1-\tau)\left(\theta_{c}+\pi_{c}(\tau)\right) .{ }^{11} \mathrm{It}$ follows that a capitalist's preferred policy $\tau_{c}$ satisfies

$$
-\theta_{c}-\pi_{c}\left(\tau_{c}\right)+\left(1-\tau_{c}\right) \frac{\partial \pi_{c}}{\partial \tau}=0
$$

Since all capitalists have identical production technologies, they all receive the same increase in profits and hence wealthier capitalists prefer lower taxes.

Fact 3 Landowners preferred policy is $\tau_{l}=0$. Capitalists have single-peaked preferences over tax rates. Moreover, the ideal policy of a capitalist $\tau_{c}$ is a decreasing function of $\theta_{c}$.

Proof: That landowners prefer a zero tax is evident.

Let $\tau_{c}\left(\theta_{c}\right)$ be the ideal policy of a capitalist with non-wage income $\theta_{c}$. Since all capitalists receive the same profits and pay taxes proportional to their total income, $\tau_{c}$ is decreasing

\footnotetext{
${ }^{11}$ From $(3),(4)$ and $(5)$, we obtain $\theta^{*}, w_{c}^{*}$ and $w_{l}^{*}$ as functions of $N$. Since $N$ is a function of $\tau$, we can write $\theta^{*}, w_{c}^{*}$ and $w_{l}^{*}$ (and hence profits and incomes) in terms of $\tau$.
} 
in $\theta_{c}$. Thus, applying the implicit function theorem to the first order condition (equation 11) we obtain

$$
\frac{\partial \tau_{c}^{*}}{\partial \theta_{c}} \equiv \frac{1}{(1-\tau) \frac{\partial^{2} \pi_{c}}{\partial \tau^{2}}-2 \frac{\partial \pi_{c}}{\partial \tau}}
$$

Finally, we only need to show that $y_{c}(\tau)=(1-\tau)\left(\theta_{c}+\pi_{c}(\tau)\right)$ is strictly quasi-concave, namely $\frac{\partial^{2} y_{c}}{\partial \tau^{2}} \equiv(1-\tau) \frac{\partial^{2} \pi_{c}}{\partial \tau^{2}}-2 \frac{\partial \pi_{c}}{\partial \tau}<0$ whenever $\frac{\partial y_{c}}{\partial \tau}=0$. But if $\frac{\partial y_{c}}{\partial \tau}=0$, the first order condition is satisfied and (11) applies, proving that $\frac{\partial^{2} y_{c}}{\partial \tau^{2}}<0$.

Industrial workers also prefer $\tau>0$ since the marginal productivity of labor in industry goes to infinity as $\tau$ goes to zero and $\frac{\partial w_{c}^{*}}{\partial \tau}>0$ (Fact 2). Letting $y_{s}(\tau)=(1-\tau) w_{c}^{*}(\tau) \theta_{\mathrm{w}}$ represent industrial workers' disposable income, all industrial workers share the same preferences over policies.

Finally, let $y_{u}(\tau)=(1-\tau) w_{l}^{*}(\tau)$ represent agricultural workers' disposable income. Unlike industrial workers, agricultural workers only benefit indirectly from the policy via the labor market clearing conditions. Therefore they may prefer a zero or a positive tax depending on whether the increase in their wage offsets the cost. Regardless, the preferred policy of agricultural workers will always be lower than that of industrial workers. ${ }^{12}$

Fact 4 Industrial workers share the same preferences over policies and favor a strictly positive policy. Agricultural workers share the same preferences over policies and always prefer a lower policy than industrial workers.

Proof: Since skilled workers' disposable income is linear in $\theta_{\mathrm{w}}$, they all share the same preferences over policies. Further, we know that $\lim _{\tau \rightarrow 0} N^{\prime}(\tau)=\infty$. It follows then from (3) and (4) that $\partial w_{c}^{*} / \partial \tau \rightarrow \infty$ as $\tau \rightarrow 0$. Therefore, $y_{s}^{\prime}(\tau) \equiv(1-\tau) \frac{\partial w_{c}^{*}}{\partial \tau}(\tau)-w_{c}^{*}(\tau)$ also goes to $\infty$ as $\tau$ goes to 0 , and skilled workers always prefer a strictly positive policy.

For agricultural workers, recall that $w_{l}^{*} \equiv \theta w_{c}^{*}$ and hence $y_{u}(\tau)=(1-\tau) \theta^{*}(\tau) w_{c}^{*}(\tau) \equiv$ $\theta^{*}(\tau) \frac{y_{s}(\tau)}{\theta_{\mathrm{w}}}$. Since $\theta^{*}(\tau)$ is decreasing in $\tau$ (Fact 2), agricultural workers always prefer lower policy values than industrial workers. Finally, since agricultural workers receive the same wage, they share the same preferences over policies.

\footnotetext{
${ }^{12}$ As it will become evident, we do not need to show that workers have single-peaked preferences.
} 


\section{$3.2 \quad$ Political Equilibrium}

We assume a simple model of two party competition in which parties $A$ and $C$ represent classes within the elite. Party $A$, the agrarian or conservative party, represents landowners and maximizes the income of its median constituent:

$$
U_{A}(\tau)=(1-\tau)\left(\theta_{l}^{M}+\pi_{l}(\tau)\right)
$$

where $F_{l}\left(\theta_{l}^{M}\right)=\frac{1}{2}$ represents the median landlord. Since all landowners prefer $\tau=0$, the preferred policy of the agrarian party is $\tau_{A}=0$.

Representing capitalists, party $C$ maximizes the income of the median capitalist:

$$
U_{C}(\tau)=(1-\tau)\left(\theta_{c}^{M}+\pi_{c}(\tau)\right)
$$

where $F_{c}\left(\theta_{c}^{M}\right)=\frac{1}{2}$. Let $\tau_{C} \equiv \tau_{c}\left(\theta_{c}^{M}\right)>0$ be the preferred policy of the liberal party. ${ }^{13}$

We assume the simplest form of political competition in which there is no uncertainty regarding electoral outcomes nor the behavior of the parties if elected. Thus, given an electorate comprised of landlords, capitalists and workers, parties put forth the preferred policy of the median voter $\left(\tau^{M}\right)$ and each party wins the election with probability one half. Given this form of competition there is no direct benefit from policy proposals since the median voter's preferred policy will be implemented (regardless of who is elected). However, there is a benefit of incumbency in that the party in power has the potential to change the franchise. Changes in the franchise alter the median voter, and hence, ceteris paribus, the welfare of each party in the subsequent election.

\footnotetext{
${ }^{13}$ Observe that some capitalists (the "poorest" ones) may prefer a higher policy than industrial workers. For the ease of exposition, we do not deal with situations where the capitalist party seeks a higher policy than industrial workers. This is equivalent to assuming a sufficiently rich median capitalist, since a capitalist's ideal policy is decreasing in his non-wage income.
} 


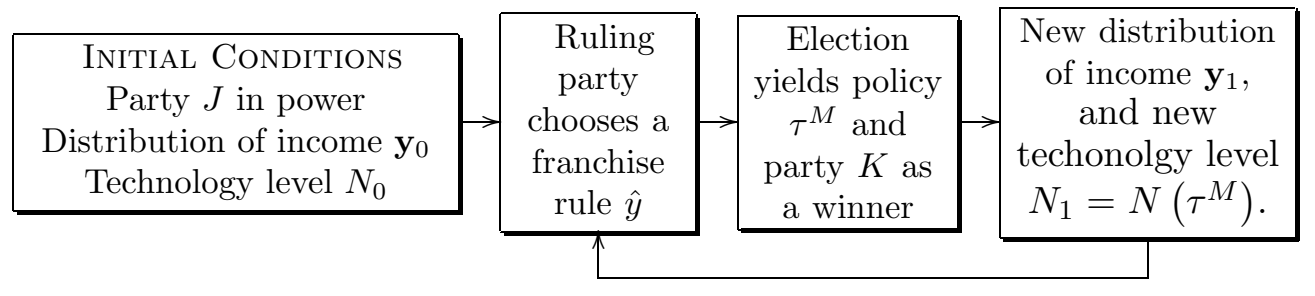

Figure 1: Timing of events.

\subsection{Franchise Rules}

Following Meltzer and Richard (1981), we assume a model of limited franchise in which classes have differentiated voting rights. Specifically, we assume that landowners and capitalists possess inalienable voting rights while the political participation of workers (who, recall, have no initial wealth) is governed by a franchise rule $\hat{y}$ representing the minimum level of gross income a worker must have to be eligible to vote. ${ }^{14}$ The franchise rule refers to pre-electoral income, which is represented by income without (new) public investment. We will refer to that segment of the population with voting rights (landowners, capitalists and workers with income larger than $\hat{y}$ ) as the electorate.

Changes in the extent of the franchise (via changes in the franchise rule) are enacted by the incumbent party. Specifically, prior to an election, the party in power can implement a change in $\hat{y}$ defining the electorate in the forthcoming election. ${ }^{15}$ The timing of events is illustrated in Figure 1. The initial conditions are fully described by the existing technological level $N_{0}$, a distribution of income $\mathbf{y}_{0}=\left\{\left\{y_{l, 0}\left(\theta_{l}\right)\right\}_{\theta_{l} \in \Theta_{l}} ;\left\{y_{c, 0}\left(\theta_{c}\right)\right\}_{\theta_{c} \in \Theta_{c}}\right.$; $\left.\left\{y_{s, 0}\left(\theta_{\mathrm{w}}\right)\right\}_{\theta_{\mathrm{w}} \in\left[\theta_{0}^{*}, \bar{\theta}_{\mathrm{w}}\right]} ; y_{u, 0}\right\}$, and a governing party $J \in\{A, C\}$. The ruling party then chooses $\hat{y}$ for the upcoming election. Once $\hat{y}$ is chosen, competition between parties yields, as de-

\footnotetext{
${ }^{14}$ An alternate approach would be to consider a franchise rule applying to all classes, not just workers. Thus, all voters must have incomes above $\hat{y}$ to be eligible to vote. This does not alter the analysis, save for introducing the potential for one class within the elite to disenfranchise the other. For example, if landowners are wealthier than capitalists party $A$ could consider a coup d'etat, disenfranchising capitalists and implementing a zero tax rate.

${ }^{15} \mathrm{We}$ choose to formalize franchise extensions as a discretionary instrument for the party in power. As Lizzeri and Persico (2004) note, historically "the extension of the franchise did not come about referendum. Rather, franchise reform was implemented by legislatures elected under limited franchise" (p.19). In our model, these legislatures are comprised of elected party members representing competing landed and industrial interests.
} 
scribed in section 3.2, a policy $\tau^{M}$. If the implemented policy $\tau^{M}>0$, there is technological advancement in the industrial sector $\left(N\left(\tau^{M}\right)>N_{0}\right)$, inducing a new distribution of income and, barring an additional change in $\hat{y}$, a new electorate. Finally, recall that $w_{c, 0}^{*} \theta_{0}^{*}=w_{l, 0}^{*}$. Hence, industrial workers have higher incomes than agricultural workers and are the first to be incorporated into the electorate as voting restrictions are eased. Only when all industrial workers are enfranchised will further reductions in $\hat{y}$ extend the suffrage to agricultural workers.

\section{The Franchise}

In this section we present our argument for changes in the franchise. We show that, depending on the circumstances, both parties may have incentives to extend the franchise.

\subsection{A Benchmark Case}

Suppose suffrage rights are restricted to the elite. That is, for an existing level of technology and distribution of income, the franchise rule is such that no worker can satisfy its

requirement $\left(\hat{y}_{0} \geq w_{c, 0}^{*} \bar{\theta}_{\mathrm{w}}\right)$. Assuming the franchise rule $\hat{y}_{0}$ cannot be changed, we have the following:

Proposition 1 Suppose the franchise rule $\hat{y}_{0}$ initially excludes all workers from voting and is kept fixed over time. Then,

(i) If $\eta_{l} \geq \eta_{c}$, the implemented tax rate will be 0 in every period.

(ii) If $\eta_{l}<\eta_{c}$, a positive tax will be implemented. Furthermore, the set of enfranchised workers will (weakly) increase over time.

Proof: If $\eta_{l} \geq \eta_{c}, \tau^{M}=0$. If $\eta_{l}<\eta_{c}, \tau^{M}>0$ and $w_{l}^{*}$ and $w_{c}^{*}$ will increase over time (Fact 2). If $\hat{y}_{0}$ does not change, some workers will eventually meet the franchise rule and obtain voting rights. Since there is no depreciation, wages will never fall and the set of enfranchised workers will (weakly) increase over time. 
This result yields two insights on the relationship between enfranchisement and growth. First, it emphasizes the importance of electoral and political institutions in achieving economic growth. In the absence of enfranchised workers, whether landlords or capitalists constitute a majority determines the character of economic growth (as discussed by Adelman, 1999). Secondly, given a majority of capitalists among the elite and a fixed franchise rule, workers will eventually be enfranchised. Thus, in some sense enfranchisement can be though of as a natural process of development. That is, given that a democratic institution exists, economic growth is good for democracy in that growth raises incomes and the ability of workers to satisfy the franchise rule in a process of "trickle-down" democracy (Justman and Gradstein, 1999).

Although $\tau^{M}>0$ when $\eta_{c}>\eta_{l}$, party $C$ cannot implement its ideal policy until industrial workers become sufficiently wealthy and satisfy the franchise rule. Specifically,

until a mass of skilled workers equal to $\eta_{l}$ are enfranchised, $\tau^{M}<\tau_{C}$. Thus, one may infer that capitalists are the first to favor extension of the franchise. However, as discussed below, our model has the potential to explain not only extensions favored by capitalists, but also those favored by agrarians.

\subsection{Altering the Franchise Rule}

We now focus on the evolution of the franchise via an incumbent's use of the franchise rule to maximize its welfare. Observe that in the absence of uncertainty about the implemented policy, parties have no incentives to implement a franchise rule different from their optimal, since they cannot alter their probability of winning. Had a party decided not to choose its optimal franchise rule in an election, it would reduce its current welfare without improving its situation in upcoming elections. As a result, we need only concern ourselves with the one period decisions of parties.

Extensions of the Franchise by Conservative Governments: Consider the case of an incumbent agrarian party. Following proposition 1, party $A$ can implement its ideal policy 
$\left(\tau_{A}=0\right)$ if $\eta_{l}>\eta_{c}$. Thus, an incumbent agrarian party will restrict the franchise to the elite in order to implement its preferred policy in the next election. ${ }^{16}$ However, our model can also explain those instances -like Germany under Bismarck or many Nordic countriesin which universal suffrage was favored by conservative political interests.

Assuming $\eta_{c}>\eta_{l}$, let $\tau_{e}^{M}>0$ be the preferred policy of the median member of the elite, and hence the policy implemented in the absence of enfranchised workers. Recall that unskilled agricultural workers prefer lower policies than industrial workers (Fact 4) and, as they are the poorest of all workers, are the last to be enfranchised under a franchise rule $\hat{y}$. Thus, if agricultural workers support policies lower than $\tau_{e}^{M}$ and if there are more agricultural workers than industrial workers, party $A$ will endorse universal suffrage. ${ }^{17}$

Proposition 2 Party $A$ will either restrict the franchise to the elite $\left(\hat{y}>w_{c, 0}^{*} \bar{\theta}_{\mathrm{w}}\right)$ or promote full suffrage $\left(\hat{y} \leq w_{l, 0}^{*}\right)$. However, party A will never support partial extensions of the franchise.

Thus, there exist situations in which an incumbent party $A$ will implement universal suffrage. Observe that agricultural workers can offset the enfranchisement of industrial workers (and thereby move the position of median voter to a citizen with a lower preferred policy) only if $\eta_{u}>\eta_{s}$ or $F_{\mathrm{w}}\left(\theta^{*}\right)>\frac{1}{2}$. Since $\partial \theta^{*} / \partial N<0$, we may observe conservatives support for universal suffrage when industrial productivity is relatively low. Such an extension does not derive from changes in social values (as in arguments regarding the enlightenment) or revolutionary threat from the disenfranchised, but rather from the strategic use of the electorate by party $A$ to manipulate implemented policies.

Extensions of the Franchise by Liberal Governments: Recall that, since $\eta_{l}>0$, party $C$ will be unable to implement its preferred policy when only the elite is enfranchised. Thus,

\footnotetext{
${ }^{16}$ For instance, the 1850 law in France enacted by the Conservatives reduced the electorate by $62 \%$ (Collier, 1999, p.42). Other examples are represented by the 1887 anti-socialist law enacted by Bismark and the unequal suffrage systems used in the 1890s by German states (Sheehan, 1978).

${ }^{17}$ Historically, the alignment of landlords' and peasants' voting behavior was not exclusively rooted in economic interests. In some instances (e.g. Switzerland, Germany, France) conservatives expected support from peasants based on religious values or support for the king. For the purpose of our analysis, this is equivalent to assuming agricultural workers' ideal policy is $\tau_{A}=0$.
} 
party $C$ will enfranchise workers until the median capitalist becomes the median voter. (Further extensions of the franchise would increase $\tau^{M}$ beyond $\tau_{C}$.) This is equivalent to extending the franchise up to the point where the enfranchised mass of workers offsets the mass of landlords. Further, if agricultural workers favor a zero or low policy, they will never be enfranchised by party $C$. Thus, extensions implemented by party $C$ will be limited in that they will never support universal suffrage.

Proposition 3 Party $C$ will always put forth a franchise rule implementing $\tau^{M}>0$ and, if possible, $\tau_{C}$. Moreover, party $C$ will enfranchise workers only to the point that the median capitalist becomes the median voter.

Proof: Since industrial workers prefer a policy greater than $\tau_{C}$, lowering $\hat{y}$ to enfranchise these workers will move $\tau^{M}$ to the right. When $\tau^{M}=\tau_{C}$, any further extensions the franchise will be opposed by party $C$ as they will move the implemented policy away from its ideal policy.

Therefore, the limit to franchise extensions promoted by liberal governments derives from two facts. First, party $C$ may be able to enfranchise just enough workers to offset the mass of landlords, thereby making the median voter the median capitalist and implementing $\tau_{C}$. Secondly, there may not be enough industrial workers to offset landlords (i.e. $\eta_{l}>\eta_{s, 0}$ ) and agricultural workers may support low policies. In such a case (which would prevail at early stages of industrial development) party $C$ will limit its extensions to industrial workers and continue to extend the franchise as workers migrate into industry (Fact 2). (Recall that for a fixed franchise rule, the fraction of enfranchised workers is growing as skilled workers receive higher wages.)

Three main conclusions follow from the analysis of the evolution of the franchise under conservative and liberal governments. First, franchise contractions are fostered by conservative governments. Second, extensions of the franchise promoted by conservative governments are larger than those promoted by liberal (capitalist) governments. Third, capitalists' support for extending the franchise has a limit: Once their place is secured (i.e. 
$\tau_{C}$ can be implemented), capitalists oppose further extensions of the franchise. We show in Section 6 that these hypothesis conform with historical evidence.

\section{Franchise, Growth, and Social Composition}

We now turn our attention to the relationship between changes in the franchise and economic growth. Of interest here is the relationship between the distribution of agent types (i.e. the share of landlords, capitalists, skilled and unskilled workers) and the distribution of political power (as characterized by the franchise rule) on implemented policies. Since policies are growth enhancing, this implies an important tie between the extent of political voice and economic growth.

\subsection{The Effect of Enfranchisement on Growth}

Suppose that landowners always vote for their party. ${ }^{18}$ In economies in which the class of landlords exceeds that of capitalists, all growth is exogenous in nature:

Proposition 4 If $\eta_{l}>\eta_{c}$, then $\hat{y}>w_{c, 0}^{*} \bar{\theta}_{\mathrm{w}}$ and $\tau^{M}=0$.

Proof: Follows from proposition 2.

Notice that in such an economy, the landed class will always win the election by restricting the franchise. Thus one might expect economies in which landed interests dominate to experience no endogenous growth (i.e. growth driven by policies promoting industrialization) and static franchise levels. Analogously, we have the following:

Proposition 5 Consider an economy in which $\eta_{c}>\eta_{l}$. Positive tax rates will prevail regardless of the incumbent party's affiliation if $\eta_{c}+\eta_{s, 0}>\eta_{l}+\eta_{u, 0}$.

Proof: Follows from propositions 2 and 3.

\footnotetext{
${ }^{18}$ This is equivalent to landowners voting for the party putting forth their most preferred policy and for the agrarian party if indifferent, and does not alter any of the previous results.
} 


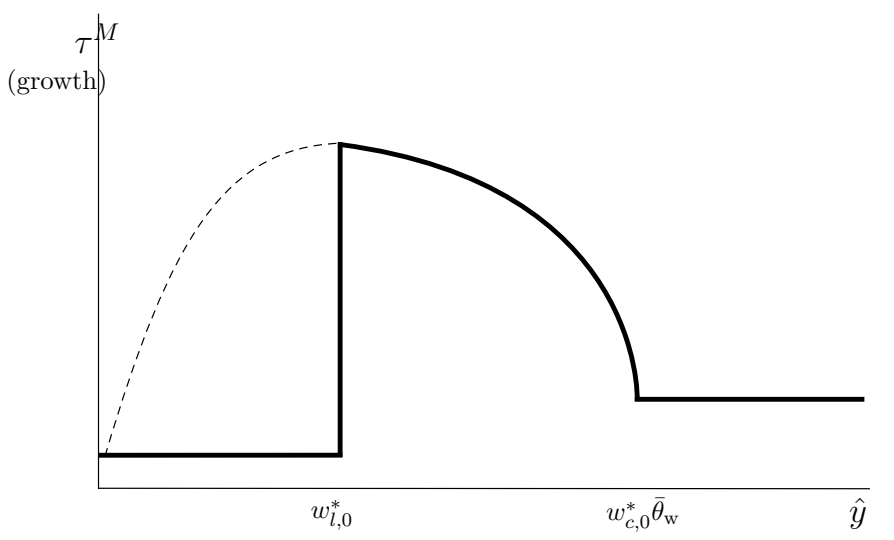

Figure 2: The relation between $\tau$ (and therefore growth through the public good) and $\hat{y}$ for an economy in an early stage of development. The dotted line represents the case of an economy with peasants holding heterogeneous policy preferences.

This implies two characteristics of an electorate are necessary for policy driven growth. First, the class of landlords must be sufficiently small so as not to outweigh capitalists and skilled workers (i.e. those always in favor of $\tau>0$ ). ${ }^{19}$ Secondly, either landlords are unable to obtain the support of agricultural workers or there exists a sufficient level of industrialization such that landed interests are unable to implement $\tau=0$. That is, recalling that $\eta_{s, 0}=\left(1-F_{\mathrm{w}}\left(\theta_{0}^{*}\right)\right) \eta_{\mathrm{w}}$, we can rewrite the condition in proposition 5 as

$$
F_{\mathrm{w}}\left(\theta^{*}\right)<\frac{1 / 2-\eta_{l}}{\eta_{\mathrm{w}}}
$$

One can think of economies with a high $\theta^{*}$ as being at an early stage of development (i.e. $N_{0}$ is low relative to $M$, and hence $\eta_{u, 0}>\eta_{s, 0}$; recall equation 3$)$. For such an economy, there exists the potential for landlords to implement $\tau=0$ by embracing universal suffrage. This enfranchises unskilled workers, choking off public investment and economic growth.

Given these insights, there exists a Kuznets-type relationship between the franchise and economic growth for democracies. When only the elites are enfranchised (i.e. $\hat{y}>w_{c, 0}^{*} \bar{\theta}$ ) parties put forth relatively low tax policies. As the franchise rule is lowered, skilled workers are extended voting rights. This raises the median voter's preferred policy, leading to higher

\footnotetext{
${ }^{19}$ This is consistent with the observations of Rueschemeyer et al. (1992) who find a politically weak agrarian elite to be perfect predictor for the survival of democracy in the interwar period (table 4.1, p.84).
} 
levels of industrial promotion and growth. However, if the franchise is fully extended and unskilled workers are given suffrage rights, the preferred policy of the median voter falls, thereby reducing parties' proposals. Figure 2 illustrates this relationship for an economy in which $\eta_{c}>\eta_{l}$ (a positive policy prevails when $\left.\hat{y}>w_{c, 0}^{*} \bar{\theta}_{\mathrm{w}}\right)$ and in which $\tau^{M}$ is lower under universal suffrage than under a franchise restricted to the elite. ${ }^{20}$

\subsection{Predictions}

In this section we summarize the predictions of the model for the relationship between the distribution of voting rights, economic growth, and the social composition of an economy (i.e. the relative masses of landed interests and aristocracy, capitalists or bourgeoisie, and industrial and agricultural workers). Taken together, propositions 4 and 5 characterize the attributes of an economy which yields endogenous growth: the class of landlords cannot be too large (proposition 4) and the economy must be at a stage of development such that (paraphrasing proposition 5) there are a sufficient number of industrial workers. This distinguishes three types of enfranchisement-growth relationships, embodied in the following "predictions" or "types" of economies. (See figure 3 and section 6.)

I Economies without a significant entrepreneurial group (capitalists) exhibit no franchise extension and low or no growth. Type I economies correspond to agrarian or pre-industrial societies where a majority of landowners among the elite (the aristocracy) control the government and oppose any extension of the franchise. These economies are at a steady-state with slow or no growth.

II Economies with a large number of capitalists but lacking a mass of industrial workers exhibit universal suffrage but low growth. Type II economies are also at an early stage of development, but the landed class promotes extensions of the franchise incorporating unskilled peasants in order to retain the control of the state. Liberals, on

\footnotetext{
${ }^{20}$ The sharp fall of the policy for $y<w_{l, 0}^{*}$ is particular to the specifications of the model. In particular, heterogeneous policy preferences among the peasantry would smooth the fall, as shown by the dotted line in the figure, displaying the more standard inverted-U shape.
} 


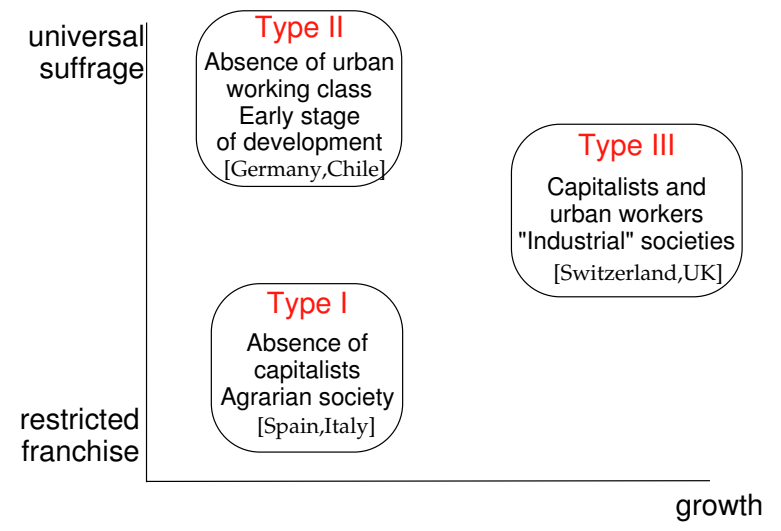

Figure 3: Predictions of the Model: Location of a different types of economies in the franchise-growth space.

the other hand, favor a far more restricted franchise. ${ }^{21}$

III Economies with enough capitalists and a substantial group of industrial (or urban) workers exhibit gradual franchise extension accompanied by high growth. Type III economics typify "industrial" economies where liberals favor and conservatives oppose franchise extension.

\section{Historical Evidence}

We analyze the nineteenth century experiences of eleven countries and find support for our theory. We focus our analysis on identifying the characteristics of electoral reform and their effects on economic policies and growth. Fundamental to our model, we seek to identify an economic cleavage among the elite. It is this conflict among the elite which leads to partisan strategizing with the franchise and affects the nature of economic development. We also show that a heterogeneity among the disenfranchised existed, driving parties to strategically extend (fully or partially) or rescind voting rights. We concentrate on the period 1850 to World War I, when electoral reforms occurred "at a very early stage of industrialization,

\footnotetext{
${ }^{21}$ During the first extensions of the franchise, many liberals and socialists leaders expressed their fear of giving the right to vote to the ignorant peasantry. The Socialist Pierre-Joseph Proudhon held that "universal suffrage given to a people of so neglected an education as ours, far from being an instrument of progress, is only the stumbling-block of liberty." (Proudhon, 1923, as cited in Colomer (2001))
} 
prior to the emergence of class-conscious workers acting as a group" (Collier, 1999, p.33) and precedes many of the historical episodes analyzed by Acemoglu and Robinson (2000).

The patterns emerging from this analysis are noteworthy: Countries implementing early limited extension of the franchise (in accord with propositions 3 and 5) were relatively early industrializers, experiencing higher levels of technological development sooner -type III economies: Britain, Sweden, and Switzerland. Countries dominated by landed interests or in which the elite were not split on an economic cleavage -type I economies: Argentina prior to 1912, Canada prior to 1898, Chile prior to 1874, France, Germany prior to 1867, Italy, and Spain- experienced restrictions of the franchise and lower levels of technological development during the nineteenth century (in accord with proposition 4). Finally, countries in which conservatives pushed for universal suffrage at relatively early stages of development -type II economies: Argentina after 1912, Chile after 1874, and Germany after 1867- saw little industrial promotion (consistent with proposition 5).

\section{Continental Europe}

Switzerland: The Swiss reform of 1848 combined the absence of revolutionary threats, an elite split on a political-economic cleavage, and a limited extension of the franchise implemented by Liberals. The free-trade stance of the newly elected Liberals and the rapid development of the railways allowed Switzerland to engage in heavy export promotion, transforming it from a pre-industrial economy prior to 1850 into one of Europe's most industrialized countries by the end of the century.

Prior to the Sonderbund War (1847), political debate in Switzerland centered around religious and economic policies: Liberals favored a secular federal state promoting commerce while Conservatives supported a decentralized confederation protecting their monopolistic power in the cantons and the authority of the Catholic Church. Given that the beneficiaries

of the traditional restrictions also held political power, Liberals called for the extension of suffrage rights (Gitermann, 1941, p.441). In response Conservatives turned to disfranchised groups, mobilizing rural supporters by "appealing to anti-urban, fundamentalist religious 
sentiment in the countryside" (Collier, 1999, p.57). ${ }^{22}$

After their victory, Liberals enacted the 1848 constitution and a limited extension of the franchise which, given the relative lack of urbanization, was less than that proposed by Conservatives and raised the electorate to approximately $31 \%$ of the population (Collier, 1999, p.58). Under the new constitution, cantons were unified under a common currency, a national postal system, standardized weights and measures, and the abolition of local toll roads within Switzerland. Most importantly, the constitution established the Federal Department of Trade and Customs and paved the passage of the railway law (1852) establishing private enterprise in railroads and facilitating trade with France and Germany (Huges, 1975). Although data on economic variables is incomplete prior to 1900, it is widely acknowledged that these reforms had a dramatic effect on Switzerland's economic character, developing the country into an industrialized economy by the end of the century (Schiff, 1971). ${ }^{23}$

France: The French case provides an example of a split elite with a dominant conservative group. This resulted in many instances of franchise restrictions, stalling industrial development and giving French economic progress a character of backwardness (O'Brien and Keyder, 1978).

Prior to 1849, the conflicting elite was integrated by two conservative groups, the Orleanists (mainly upper bourgeoise of Paris, the financial sector, and increasingly the railroads) and the Legitimist (aristocracy favoring the Bourbon monarchy). The Restoration regime attempted to base its rule narrowly on the nobility, and the 1830 suffrage restriction eliminated all but the richest landowners from the electorate (proposition 2). Its subsequent downfall allowed Orleanists to enact a limited extension (proposition 3) ensuring that "the

\footnotetext{
${ }^{22}$ In accord with proposition 2 Conservatives "did not oppose democracy; on the contrary, they sought to extend it and mobilize their followers against the Liberals" (Rueschemeyer et al., 1992, p.86). Observe that this behavior cannot be explained by models emphasizing revolutionary threats, e.g. Acemoglu and Robinson (2000).

${ }^{23}$ For example, the reductions in the costs of trade, along with the virtual absence of patent laws, allowed Swiss chemical producers in the 1850's to implement British developed procedures for the manufacture of aniline dyes. By 1899, the value of Swiss dye production (90\% of which was exported) exceeded that of both Britain and France. See Schiff (1971).
} 
upper bourgeoisie, particularly those sectors based in Paris and in finance, and not the artisans that did the street fighting," were the primary beneficiaries (Rueschemeyer et al., $1992, \mathrm{p} .88) \cdot{ }^{24}$

In May 1849, the petty bourgeoisie and professionals organized and obtained victories in 21 of 30 by-elections (Rueschemeyer et al., 1992, p.90). As a consequence, conservatives enacted the 1850 reform, reducing the electorate by 2.8 million men and concentrating policy making in the hands of conservatives (Collier, 1999, p.42). This permitted legal changes making English-style banking impossible, creating crises for financing capital and effectively stalling the railways, the iron industry, commodity imports and contributing to France's heteroclite pattern of nineteenth century growth (O'Brien and Keyder, 1978). By effectively stopping industrial development, these changes also stalled rural emigration, further slowing the transformation of agrarian institutions and the adoption of newer industrial technologies.

Germany: The 1848 liberal revolution represented the first extension of the franchise in Germany. Liberals, a blend of educated and political elite, sought to remove the abuses of the existing political system through a restricted extension of the franchise (Sheehan, 1978, p.69-70). Liberals were "deeply suspicious of the masses, considering lacking in independence" and welcomed franchise restrictions that served as buffers between the political elite and the people (Blackbourn, 1998, p.234).

The next major political reforms in Germany were enacted by conservative governments. By 1860 economic development was having an unmistakable impact on Germany and data on Prussian elections between 1858 and 1866 (and the scattered data available on other states) show that liberals drew their strongest support from the economic elite in cities (Sheehan, 1978, p.81). In response, Bismarck, the conservative prime minister of Prussia, established universal suffrage in the Northern German Confederation (1867) and in the

\footnotetext{
${ }^{24}$ The reform enfranchised only 1 in 170 inhabitants. Interestingly, both parties opposed further extensions beyond the 1830's levels, with Orleanists supporting the existing restricted suffrage and Legitimists favoring a return to a more restricted franchise. See also Magraw (1983, p.48-49,68).
} 
unified empire (1871) based on his political calculations to swamp liberalism. ${ }^{25}$

He [Bismarck] wanted a democratic suffrage because he was convinced that the majority of the Germans would be committed upon to elect a cooperative parliamentary elite. In order to ensure that this would happen, the chancellor wanted to combine universal male suffrage with three other provisions ... designed to produce what would remain Bismarck's ideal representative body: a group of propertied men, drawn from landed and business elite. (Sheehan, 1978, p.145)

In line with our analysis (proposition 2), a politically weak opposition, a small workingclass movement (which was not consolidated until 1875), and the expected support of the rural population motivated Conservatives to introduce full (male) suffrage and preserve the conservative order. ${ }^{26}$ This allowed Bismark to pursue economic changes favored by the agricultural society in Prussia (Barkin, 1970), like reductions in tariffs (which expanded German grain markets with little effect on domestic prices) and legal changes encouraging money wages rather than in-kind wages and sharecropping (thereby allowing landed interest to lower the real incomes of agricultural workers who had gained from high grain prices).

Summarizing, "neither the unequal manhood suffrage of 1848 in Prussia nor the equal suffrage of 1867 and 1871 in the Confederation and Reich respectively was the result of -or, indeed, attended by- working-class pressure" (Collier, 1999, p.103). On the contrary, while the 1848 liberal revolution established a restricted extension intended to remove the abuses of the existing political system (Sheehan, 1978, p.69-70), the 1860s and 1870s saw "the establishment of the principles of full suffrage as part of a conservative strategy from above [over the heads of the liberal opposition and with the objective to swamp liberalism], and it was not accompanied by other components of a democratic regime, specifically parliamentary sovereignty, civil liberties, or, in Prussia, equality of the vote" (Collier, 1999,

\footnotetext{
${ }^{25}$ See Colomer (2001, p.60), and Collier (1999, p.102-103), among others. Liberals themselves accused Bismark of "stirring up the poorer classes against the propertied middle class" (Blackbourn, 1998, p.255-56).

${ }^{26}$ Interestingly, when socialists started to take advantage of these electoral reforms, Bismarck responded with the anti-socialist laws of 1878. Observe that it is after this period that Acemoglu and Robinson (2000) find evidence in support of their argument.
} 
p.104).

\section{Anglo countries ${ }^{27}$}

The United Kingdom: The case of Britain has received the most attention by political scientists and economists. The main political reforms in nineteenth century Britain (1867 and 1884) are commonly viewed as directed towards incorporating the lower classes into the electorate. These reforms demonstrated the strategic possibilities of seeking labor support, and "once reform had been put on the agenda, the parties competed for the ability to shape it, to cast it in a form to their benefit" (Collier, 1999), with Liberals striving for limited extensions and Conservatives favoring broader suffrage rights (Lee, 1944; Smith, 1967).

Three main implications follow from the analysis of Britain's 'Age of Reform'. ${ }^{28}$ First, pre-reform governmental institutions were under the control of a subgroup within the elite. Hence, political reforms and the accompanying economic policies favored commercial and urban classes within the elite. Industrial and commercial factions saw in political reform a way of ending a situation where their "policies were blocked in a Parliament that disproportionately represented the landed groups" (Collier, 1999, p.62). Second, progressive franchise extensions were closely linked with rapid urbanization. Finally, the observed increases in public spending were devoted mainly to infrastructure (not redistribution), thereby raising domestic industrial productivity and facilitating commerce. These findings are fully consistent with our theory and, combined with high economic growth, show Britain as an exemplar of a type III economy.

Canada: In Canada the evolution of the franchise involved piecemeal extensions and reductions in which control over electoral rules served as a political tool for promoting the

\footnotetext{
${ }^{27}$ While many of the franchise changes in the United States are consistent with our model, it is difficult to disentangle various confounds in the U.S. experience. Specifically, many of the changes in the electorate were implemented at the state level (often under federal electoral law) and are strongly influenced by issues most germane to the states in which they were enacted. Changes in literacy and income rules and the implementation of policies such as voluntary registration were under the control of state and local governments and had profound effects on the distribution of voting rights. Thus, given the potential tensions between federal and state governments and the specificity of many state issues, we have chosen to abstract from the United States in the following analysis.

${ }^{28}$ We refer the reader to Lizzeri and Persico (2004) for details and references.
} 
economic policies of those in power. For example, migration and strong commercial ties between Vancouver and San Francisco created a movement for amalgamation of British Columbia with the United States. Fearing the loss of this rich resource base (and a domino effect against confederation in other Western provinces), Conservatives required voters be born British citizens, thereby eliminating the votes of U.S. and immigrant settlers (Ryerson, 1968). The Conservative's Electoral Franchise Act (1885) imposed similar voting requirements effectively restricting the franchise to agricultural elites and allowing a protectionist stance against the U.S. (Ryerson, 1968) Consistent with a type I economy, the policies implemented under this restricted franchise slowed industrial development and income growth: over the period 1870 to 1896, "Canada did not have the internal driving force to provide its own dynamics. Without this capital inflow, there would undoubtedly not have been as much growth" (Green and Urquhart, 1994, p.172).

Consistent with liberal interests favoring limiting expansion, much of the Act was reversed (1898) when Liberals implemented a limited extension and returned electoral rules

to provincial control. This extension permitted policies reducing trade barriers, providing incentives for greater investment (which reduced transport and handling costs), and encouraging western settlement. These changes facilitated the "wheat boom," ushering in a period of export-led growth (Green and Urquhart, 1994).

\section{Nordic Countries}

Denmark: There is no evidence in the Danish case of a government forced to offer expansions of the suffrage against its will. On the contrary, in the electoral issue parties were driven by self-interest: "their main objective was to ensure for themselves as much parliamentary (and of course bicameral) bargaining power as possible, since that would allow them to pursue policy objectives more efficiently" (Elklit, 2002, p.36).

During the nineteenth century, the bourgeoisie and a rural middle class coalition ("independent owners of moderately sized farms" who had become "small capitalist traders" opposing the great proprietors; Hovde, 1943) pushed for democratization, although Con- 
servatives (with the support of the king) maintained power without any major reform of the political system. During this period, the basic rural/urban cleavage was the dominant social and cultural divide, clearly reflected in a simple Conservative-Liberal party system (Elklit, 2002, p.36).

When Liberals obtained power in 1901, the Social Democratic party (appealing to the growing working class) was consolidated. Hence, in accordance with the best interest of its constituency, the Liberal party froze any electoral change which would have enfranchised supporters of this group. Once more, a Liberal party in power stalls further extensions of the franchise when it does not expect to receive the votes of the new potential voters. ${ }^{29}$

Sweden: In Sweden democracy arrived via a series of gradual franchise extensions. The Swedish reform of 1866 "represented the fulfillment of the program of [the] early nineteenthcentury bourgeois Liberals" configured by non-noble ironworks owners, wholesalers, nonnoble landed proprietors, and prosperous farmers (Rueschemeyer et al., 1992, p.93; our italics). This reform replaced the estate system with a new two chamber system and, while only a moderate extension, the reform had a significant effect on the character of Swedish economic growth, giving it the earmarks of a type III economy. ${ }^{30}$ For example, the 1866 reform permitted the removal of legislation restricting output to support domestic prices, fostered industrial development by providing incentives for technology adoption, liberalized imports, and opened the door for the electrification in industrial production (Heckscher, 1963). As a result, by 1880 Swedish iron production exceeded that of both France and Germany (Schiff, 1971).

Suffrage does not again become an issue until the last decades of the 19th century, when a debate over free trade split the Agrarian Party into a new Conservative Party

\footnotetext{
${ }^{29}$ See Elklit (2002, p.30-36) for a description of the strategy followed by the Liberal Prime Minister (J.C. Christensen) to "avoid any decisions that would eventually inflict losses on him and his party".

${ }^{30}$ The First Chamber represented the wealthy and socially prestigious, and was the preserve of the right. The Second Chamber was dominated by the Agrarian Party, primarily based on farmers who represented small landed proprietors and constituted the engine for growth. Note that, according to their economic interests, the Swedish Agrarian Party does not identify with the Conservative but with the Liberal party in our model. This points becomes clear by the end of the 19th century when the Swedish Agrarian Party split on the protectionism/free-trade cleavage, configuring a Conservative-Liberal party system.
} 
(formed from "most of the Agrarian Party and a parliamentary faction of the right") and a Liberal Party (a "broad-based political force with its roots in the free-trade tendency"). Not surprisingly, following the split, "the suffrage issue [promoted by the liberals and fought by conservatives] constitutes the ideologically most potent dividing line between left and right" (Särlvik, 2002, p.234). Thus it is in the split of the elite along trade policy where we find the origin of the franchise issue.

\section{Latin Europe: Italy and Spain}

The patterns of enfranchisement and growth exhibited by Italy and Spain (i.e. those of a type I economy) are consistent with our model given an elite dominated by landed interests and therefore no impetus for franchise extension nor industrial development.

Politically, a common element to the Italian and Spanish experiences is the absence of a split elite. ${ }^{31}$ This concurrence of elite interests resulted in the transformismo/el Turno systems that effectively fixed electoral outcomes, stalling franchise expansions until the years around World War I. ${ }^{32}$ Economically, this consolidation of political power resulted in "an industrial revolution manqué" (Harrison, 1978). In both countries, ruling interests blocked the formation of internal markets and sought a highly protective state, as evidenced by tariffs in 1887 (Italy) and 1891 (Spain). These policies slowed the processes of urbanization and industrialization, creating an environment in which the favoritism paid to to entrenched interests alienated foreign investment and trade. Neither country could effectively shift labor from low productivity agricultural sectors into burgeoning industrial sectors, thereby stalling economic growth (Clough, 1964; Nadal, 1987). For example, both Italy and Spain lagged far behind other industrializing countries in the production of textiles and steel, patterns reflected in the countries' growth of national income and level of industrial development (Nadal, 1987; Schiff, 1971).

\footnotetext{
${ }^{31}$ For instance, the Spanish land reforms of the 1850s opened the possibility of landowning for the affluent nobility, the upper peasantry, local political bosses, and the bourgeoisie, thereby merging their economic and political interests (Rueschemeyer et al., 1992, p.119)

${ }^{32}$ In Italy, it was not until after World War I that mass electoral enfranchisement was implemented (Colomer, 2001, p.56-57). In Spain, the military coup of 1923 ends the corruption of El Turno, instituting a short-lived, but highly democratic, Republic.
} 


\section{Latin America: Argentina and Chile}

Sokoloff and Engerman (2000) and Engerman and Sokoloff (2001) point out how strikingly limited the franchise was in Latin American during the nineteenth century. The political (and economic) power in these countries was concentrated in the hands of a landed aristocracies; the lack of an active capitalist group made it impossible for the type of electoral reforms which would have paved the way for active industrial policies.

Prior to the 1870's, dominating landed interests imposed literacy and wealth requirements (along with informal policies subordinating the legislatures), thereby restricting the electorates in Argentina and Chile (Collier, 1999; Colomer, 2004; Sokoloff and Engerman, 2000). The absence of a viable capitalist class permitted landed interests to pursue policies which consolidated land-holding among the elite (Gerstein, 2000) and biased domestic infrastructure (namely railroads) in favor of agricultural exports (Lingarde and Tylecote, 1999). The result was the virtual neglect of urban infrastructure, economic institutions (e.g. a financial sector providing capital to small industrialists), and industrial development. As a result, both Argentina and Chile typify as type I economies throughout most of the nineteenth century. Their classification changes though for the last decades.

Through the 1880's, Argentina saw significant increases in foreign investment (including 5,800 miles of British owned railroads), international trade (focused on agricultural goods), and immigration (Rock, 1985, p.132). As a result, the elite was split between a conservative landed elite (pressing for subsidies and trade credits) and a growing liberal fraction espousing free trade and changes in foreign policy. This cleavage paved the way for the 1912 electoral reforms: concordant with proposition 2, conservative leader Sáenz Peña enacted universal suffrage and compulsory voting, permitting the traditional elite to maintain political and economic power, typifying a type II economy.

Similarly, in the Chilean reform of 1874 Conservatives endorsed a reform eliminating voting restrictions (except literacy) and establishing impartial juntas with the oversight of registration lists (Collier, 1999, p.60). In accord with proposition 2, conservatives pushed for greater suffrage, enfranchising those considered supportive of conservative policies (Valen- 
zuela, 1996). As predicted, Chilean economic growth lagged behind other countries both before and after the 1874 reforms: economic policies favored agricultural and mineral exports, investing little in urban services (Mamalakis, 1976). As with Argentina, conservatives' large extensions of the franchise and control over economic policies casts Chile as a type II economy in which "the increments in productive infrastructure that might have had a lasting effect on the economy's capacity to modernize and transform itself remained small." (Mamalakis, 1976, p.27)

\section{Conclusion}

Research on issues of growth and development are increasingly turning to the analysis of the distribution of political power in delineating the ability of an economy to realize its potential. As Sokoloff and Engerman (2000) demonstrate, while factor endowments play an important role in economics development, the full returns of these endowments are rarely realized when the distribution of political power (and hence decision-making rights over economic policy) is concentrated among the elite. Our analysis sheds light on these findings. In particular, identifying the role of suffrage rights as a tool in partisan competition helps explain how voting rights are allocated among the population. This distribution of political voice in turn determines the way a government invests, expands markets, and generally fuels the process of development.

We find in the social structure of society an explanation for the connection between enfranchisement and growth. When (1) there exist an economic conflict among the elite, (2) the landed classes are not politically strong, and (3) there exists a critical mass of urban (industrial) workers, we observe both growth and democratization. The lack of conditions (1) or (2) resolves in stagnant autocracies while the absence of condition (3) drives growthdeterring democratic expansions. It also follows from our analysis that we should observe (i) franchise contractions are mostly fostered by conservative governments, $(i i)$ franchise extensions promoted by conservative (agrarian) governments tend to be larger than those 
promoted by liberal (capitalist) governments, and (iii) there exists a limit to capitalists' support for extending the franchise. These observations are, in turn, largely supported by historical evidence across a host of countries.

We conclude with two words of caution. First, we do recognize the role played by the working class in the final push of democratization. However, in most cases the working class was not strong enough to start the process of democratization. As an indicator of this, Therborn (1977) points out that in no case did the working class parties received electoral majorities even after the introduction of universal suffrage. Hence, our argument aligns with Rueschemeyer et al. (1992) when they note that "not only did the working class need allies in other classes in this final push, other classes were, in many cases, more important in earlier extensions of the suffrage and/or struggles for parliamentary government" (p.83). Secondly, our model does not adequately account for cases of high growth combined with large extensions of the franchise. Such patterns have been observed in the late reforms of some Northern European countries by changing political institutions from majority to proportional representation. We leave this issue for future research.

\section{References}

Acemoglu, D., Robinson, J. A., 2000. Why did the West extend the franchise? Democracy, inequality, and growth in a historical perspective. Quarterly Journal of Economics 140 (4), $1167-1200$.

Acemoglu, D., Robinson, J. A., 2001. A theory of political transitions. American Economic Review 91, 938-963.

Adelman, I., 1999. The role of government in economic development, Department of Agricultural and Resource Economics and Policy. University of California at Berkeley. Working Paper No. 890.

Barkin, K. D., 1970. The Controvery Over German Industrialization: 1890-1902. University of Chicago Press, Chicago.

Benabou, R., 2000. Unequal societies: Income distribution and the social contract. American Economic Review 90, 96-129.

Bertocchi, G., 2003. The law of primogeniture and the transistion from landed aristocracy to industrial democracy. Discussion Papers 3723, CEPR. 
Blackbourn, D., 1998. The Long Nineteenth Century. A History of Germany, 1780-1918. Oxford University Press, Oxford.

Bourguignon, F., Verdier, T., 2000. Oligarchy, democracy, inequality and growth. Journal of Development Economics 62, 285-313.

Clough, S. B., 1964. The Economic History of Modern Italy. Columbia University Press, New York.

Collier, R. B., 1999. Paths Towards Democracy: The Working Class and Elites in Western Europe and South America. Cambridge University Press, New York.

Colomer, J. M., 2001. Political Institutions: Democracy and Social Choice. Oxford University Press, New York.

Colomer, J. M., 2004. Taming the tiger: Voting rights and political instability in latin america. Latin American Politics and Society 46 (2).

Conley, J. P., Temimi, A., 2001. Endogenous enfranchisement when groups' preferences conflict. Journal of Political Economy 109 (91), 79-102.

Elklit, J., 2002. The politics of electoral system development and change: The Danish case. In: Grofman and Lijphart (2002), Ch. I, pp. 15-66.

Engerman, S. L., Sokoloff, K. L., 2001. The evolution of suffrage institutions in the New World. Working Paper 8512, NBER.

Fleck, R. K., Hanssen, F. A., July 2002. The origins of democracy: A model with applciation to ancient Greece, working paper.

Galor, O., Moav, O., Vollrath, D., 2002. Divergence and overtaking: Land abundance as a hurdle for education reform. Department of Economics Working Paper 2002-11, Hebrew Universty.

Gerstein, F. S., 2000. Argentina. American Journal of Economics and Sociology 59 (5), 49-63.

Gitermann, V., 1941. Geschichte des Schweiz. Agustin-Verlag, Thayngen.

Green, A. G., Urquhart, M. C., 1994. Estimates of output growth in Canada: Measurement and interpretation. In: McCalla, D., Huberman, M. (Eds.), Perspectives on Canadian Economic History, 2nd Edition. Copp Clark Longman Ltd., Mississauga, Ontario, pp. $158-177$.

Grofman, B., Lijphart, A. (Eds.), 2002. The Evolution of Electoral and Party Systems in the Nordic Countries. Argathon Press, New York.

Harrison, J., 1978. An Economic History of Spain. Manchester University Press, Manchester. 
Heckscher, E. F., 1963. An Economic History of Sweden. Harvard University Press, Cambridge.

Hovde, B. J., 1943. The Scandinavian Countries,1720-1865: The Rise of the Middle Classes. Vol. 2. Chapman and Grimes, Boston.

Huges, C., 1975. Switzerland. Ernest Benn Limited, London.

Justman, M., Gradstein, M., 1999. The industrial revolution, political transition, and ths subsequent decline in inequality in the 19th-century Britain. Explorations in Economic History 36, 109-127.

Lee, S. J., 1944. Aspects of British Political History, 1815-1914. Routledge, London.

Lee, W., 2003. Is democracy more exprorpiative than dictatorship? Tocquevillian wisdom revisited. Journal of Development Economics 71 (1), 155-198.

Lingarde, S., Tylecote, A., 1999. Resource-ruch countries' success and failure in technological ascent, 1870-1970: The Nordic countries versus Argentina, Uruguay, and Brazil. Journal of European Economic History 28 (1), 77-112.

Lizzeri, A., Persico, N., 2004. Why did the elites extend the suffrage? Democracy and the scope of government with an application to Britain's "Age of Reform". Quarterly Journal of Economics 119 (2), 707-765.

Llavador, H., Oxoby, R. J., 2002. Enfranchisement and political competition, mimeo.

Magnac, T., Postel-Vinay, G., 1997. Wage competition between agriculture and industry in mid-nineteenth century France. Explorations in Economic History 34, 1-26.

Magraw, R., 1983. France 1815-1914: The Bourgeois Century. Fontana, Oxford.

Mamalakis, M. J., 1976. The Growth and Structure of the Chilean Economy. Yale University Press, New Haven.

Meltzer, A. H., Richard, S. F., 1981. A rational theory of the size of government. Journal of Political Economy 89 (5), 914-927.

Morris, C., Adelman, I., 1988. Compative Patterns of Economic Development, 1850-1914. Johns Hopkins University Press, Baltimore (Md.).

Nadal, J., 1987. A century of industrialization in Spain, 1833-1930. In: Sànchez-Albornoz, N. (Ed.), The Economic Modernization of Spain, 1830-1930. New York University Press, New York.

O’Brien, P., Keyder, C., 1978. Economic Growth in Britain and France: 1978-1914. Allen and Unwin, London.

Parente, S., Zhao, R., 2002. From bad institutions to worse: The role of history in development, mimeo. 
Persson, T., Tabellini, G., 1994. Is inequality harmful for growth? American Economic Review 84 (3), 600-621.

Proudhon, P.-J., 1923. Ouvres Complètes. M. Rivière, Paris.

Rock, D., 1985. Argentina 1516-1982. University of California Press, Berkeley.

Rueschemeyer, D., Stephens, E. H., Stephens, J. D., 1992. Capitalist Development \& Democracy. Polity Press, Cambridge.

Ryerson, S. B., 1968. Unequal Union. Progress Books, Toronto.

Saint-Paul, G., Verdier, T., 1993. Education, democracy, and growth. Journal of Development Economics 42 (2), 399-407.

Särlvik, B., 2002. Party and electoral system in Sweden. In: Grofman and Lijphart (2002), Ch. V, pp. 225-269.

Schiff, E., 1971. Industrialization Without National Patents: Netherlands, 1869-1912, and Switzerland, 1850-1907. Princeton University Press, Princeton.

Sheehan, J. J., 1978. German Liberalism in the Nineteenth Century. The University of Chicago Press, Chicago.

Smith, P., 1967. Disraelian Conservatism and Social Reform. Routledge and Kegan Paul, London.

Sokoloff, K. L., 2002. The evolution of suffrage institutions in the new world: A preliminary look. In: Haber, S. (Ed.), Crony Capitalism and Economic Growth in Latin America: Theory and Evidence. Hoover Institution, Ch. 3, pp. 75-108.

Sokoloff, K. L., Engerman, S. L., 2000. Institutions, factor endowments, and paths of development in the new world. Journal of Economic Perspectives 14 (3), 217-232.

Therborn, G., 1977. The rule of capital and the rise of democracy. New Left Review 103, $3-41$.

Toynbee, A., 1884. The Industrial Revolution. Beacon Press, Boston.

Valenzuela, J. S., 1996. Building aspects of democracy before democracy: Electoral practices in nineteenth century Chile. In: Posada-Carbó, E. (Ed.), Elections Before Democracy: The History of Elections in Europe and Latin America. St. Martin's Press, New York, Ch. 10, pp. 223-258. 